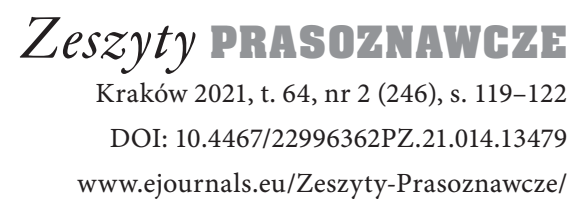

\title{
THEN, NOW, AND LATER: THE TRANSITION OF DOCUMENTARY PHOTOGRAPHY
}

\author{
Michelle Bogre: Documentary Photography Reconsidered: \\ History, Theory and Practice, London and New York: \\ Bloomsbury Visual Arts, an imprint of Bloomsbury \\ Publishing, Plc, 2019, 264 pages.
}

Michelle Bogre's “Documentary Photography Reconsidered” offers a fascinating discussion on the transformation of documentary photography. The book consists of a foreword written by Stephen Mayes, an introduction, five chapters and an extensive resource list.

"Documentary Photography Reconsidered" provides readers with the opportunity to reflect upon early documentary work and contemporary documentary practices by making creative connections between past, present, and future that shatter the rigid distinction between the analogue and digital age and reveal how current transformation of documentary photography is interlinked with past practices. Bogre rewrites the history of documentary photography offering both linear and non-linear reading processes that allow readers to both follow and actively participate in the discourse. This active engagement reflects what the current electronic culture enables us to do. We both consume and create content, and similarly we are invited by Bogre to both learn about documentary photography and add our voice to the ongoing debate on its transformation. The open structure of the book allows, therefore, for fluid interpretations depending on the culture, knowledge, and experiences of the reader.

At the linear level, Bogre reconsiders how documentary photography has been changing as memory, evidence, narrative, and a tool for social activism. Bogre approaches documentary photography from two perspectives: photographer and viewer, inviting us to consider both the ethics of photographing and the ethics of viewing. The rich textual analysis of photographs accompanied by a diverse range of images allow us to examine how form and content work together to create political meanings that construct our collective memory and views of sociocultural and historical reality. At the non-linear level, Bogre encourages us to create our own narrative by completing assignments and exploring other documentary works listed in the resource section. In addition to this, Bogre includes interviews with the featured photographers that are also available to watch on the book's companion 
website. The reader can discover documentary photography at their own pace. Bogre does not impose on us a fixed point of view but creates an interdisciplinary and multidimensional discourse that combines both theory and practical suggestions.

In the first chapter Bogre introduces the concept of documentary photography and provides a solid basis for further discussion about the relationship between photography on the one hand, and history, truth, authenticity, and reality on the other hand. Through the analysis of early documentary photographs Bogre reveals the problematic status of documentary photography as historical proof. According to the scholar, early documentary photographs remain important historical records, but they must be analysed in the context of the Western colonial gaze - the gaze of an outsider that produces distorted representations of other cultures (p. 40-41). Bogre argues that photographing people and events imposes on us all a collective responsibility. While the photographer has to represent their subjects ethically, viewers must thoroughly analyse the images (p. 60). Further, Bogre discusses the documentary photography's transformation from practical and philosophical perspective and analyses the impact of digital manipulation and social media on the photograph's authenticity.

In the second chapter Bogre examines the relationship between photography and memory. Bogre argues that documentary photography has played an important role in preserving the memory of people and cultures (p. 118). Digital technology has, however, changed how we form the collective memory. While in the past people viewed the same images together at almost the same time, now we see the same images virtually at different times (p. 78). Moreover, Bogre observes that digital technology has impacted our trust in the photograph: with images circulating around the Internet without context, their authenticity is called into question (p. 118). "How will we know which images we can trust 50 years from now?" (p. 119), Bogre asks inviting us to reflect on the future role of documentary photography in creating memory. Within the chapter Bogre also discusses how images can both implant and correct false memories. As an example, she provides Eddie Adams's iconic Vietnam War execution photo which was misunderstood due to people not knowing its real context (p. 79-80). The counterexample constitutes the 19th century documentary portraitures of Frederick Douglass and Sojourner Truth that offer an alternative narrative to how former slaves were portrayed in the 19th century (p. 84-85). By including images that counter visual stereotyping of the marginalised groups, Bogre gives a symbolic voice to those whose history remained misunderstood for a number of years making the book an important contribution to the current debates on race, history, and visual misrepresentation.

The third chapter is devoted to the analysis of documentary photography as evidence. Borge further examines how digital technology has impacted our trust in the photograph and discusses how photography has been used since the 19th century to document and provide proofs. The author starts her analysis with a discussion of early mugshots that were used by police departments to photograph criminals. As opposed to modern mugshots, they possessed creative qualities (p. 125). This is a particularly intriguing observation in view of the fact that the shots were used 
for administrative purposes. What is more, their "artistic flair" (p. 125) reveals that early photographs used as evidence by the State were unburdened from the rigid distinction between documentary and art. The point that could meaningfully contribute to the ongoing debates over whether or not documentary photographers should use creative shots as evidence. Further, Bogre explores how documentary photography has been used as a starting point to discuss political issues. The project of Edmund Clark and Crofton Black Negative Publicity: Artefacts of Extraordinary Rendition is a particularly interesting example of how a lack of visual proof can be as powerful as what we can see (p. 139) and what is more, how image redaction does not contravene the power of photography to reveal politically important subjects. This raises the question whether digital manipulation could always be used as a way of telling the truth, regardless of the represented issue or subject. Are there any risks of using this technique as a method of creating evidence? Does our trust in the redacted photograph impact our engagement with the image? Further elaboration of these ideas could enrich the discussion of visual ethics.

The fourth chapter focuses on the role of the documentary photographer as witness. Bogre begins her discussion with the observation that witnessing is always subjective as it depends, among other things, on how the photographer decides to shoot the scene (p. 158). Being a witness brings us back to the question of ethics and responsibility in the digital age. According to Bogre, with the wide reach of social media, it is even more important now for documentary photographers to consider the agency of the subjects and monitor how their photographs are being used (p. 158). Further, Bogre analyses how digital technology has impacted the status of witness. As nowadays, everyone can use their mobile phones to take pictures, the author rightly raises the issue whether we can trust the images taken by the photographers we have never heard of (p. 172). The author goes on to conclude that as we cannot always believe photographs to be true representations, we need to trust the photographer (p. 179). Unfortunately, Bogre does not give any suggestions, as to how we can go about navigating the issue of photographs taken by amateurs or beginner photographers whose reputation is not established. How should we approach the images taken by the photographers whose career has just started? Does the lack of established reputation of the photographer always render their photographic evidence questionable? Answers to these questions could help us both evaluate our engagement with amateur photography and consider its meaning and significance within the collective memory. The book ends with the chapter discussing ten intriguing documentary photography projects that create narratives by means of traditional narrative conventions or use new forms of storytelling that are not strictly documentary.

Summing up, "Documentary Photography Reconsidered" is an exceedingly valuable discussion of documentary photography. The analysis of ethical issues deepens our understanding of the role we play as viewers and photographers and invites us to read images with a new awareness and consciousness. The book offers an interesting bridge between the theoretical approach and the practical one allowing us to reconsider documentary photography from multiple perspectives and actively 
participate in the discourse. The book also raises a plethora of other interesting issues which, due to the limited scope of my review, would be worth discussing separately. While I would greatly appreciate a bit more elaboration on the issue of using digital manipulation as a way of telling the truth and the engagement with the photograph-evidence taken by amateur photographers, I am also aware of the author's intention which as mentioned in the introduction is to leave us with questions. "Documentary Photography Reconsidered" will definitely benefit readers who wish to be more aware of the meanings constructed by images. It is an intriguing and thought-provoking work so much needed in times in which we are exposed to more images than ever before.

Weronika Saran

(iD) orcid.org/0000-0003-2430-0510 